\title{
Biopsy Specimen
}

National Cancer Institute

\section{Source}

National Cancer Institute. Biopsy Specimen. NCI Thesaurus. Code C18202.

A specimen obtained by biopsy, which is a process of removing tissue from living patients for diagnostic examination. 